DOI:

http://dx.doi.org/10.15448/1983-4012.2017.2.29486

\title{
POR UMA FENOMENOLOGIA DA LINGUAGEM
}

\author{
For a Phenomenology of Language
}

Luiza Helena Hilgert*

Resumo: Entendendo que o ato primeiro da consciência é propriamente significar e que compreender o homem como ser significante isto é, que atribui sentido às próprias vivências implica em inscrevê-lo como ser de linguagem, o presente artigo visa inserir o problema da linguagem como questão fundamental da discussão fenomenológica. Consciente da impossibilidade de abordar o problema da linguagem em toda a tradição fenomenológica, realizo dois recortes: um temático e outro de autores. Procuro pensar o estatuto da linguagem na fenomenologia circunscrevendo o problema nas noções de expressividade, verdade e comunicação a partir do resgate da fenomenologia de Husserl e Heidegger, mas com vistas a centrar o estudo no debate entre JeanPaul Sartre e Maurice Merleau-Ponty.

Palavras-chave: Expressividade, Verdade, Comunicação, Sentido, Significação.

\begin{abstract}
We understand as the first act of consciousness the act of giving meaning, think man as being that gives meaning to our own experiences means to inscribe him as a being of language, this paper inserts the problem of language as a privileged debate of phenomenological discussion. We are aware of the impossibility to study the theme of language throughout the whole phenomenological tradition, so we are guided by the conceptual and historical frameworks. This article aims to analyse the status of language in phenomenology circumscribing the problem on the notions of expressiveness, truth and communication since the Husserl and Heidegger's phenomenology to focusing the study on the debate between JeanPaul Sartre and Maurice Merleau- Ponty.
\end{abstract}

Keywords: $\quad$ Expressiveness, Truth, Communication, Sense, Meaning.

* Doutora em Filosofia pela Unicamp e Université Paris VIII. Bolsista FAPESP. Professora temporária do departamento de Filosofia na UFES. E-mail: luizahilgert@ hotmail.com

\begin{tabular}{|c|c|l|l|c|c|}
\hline intuitio & $\begin{array}{c}\text { ISSN } \\
1983-4012\end{array}$ & Porto Alegre & Vol.10- $\mathrm{N}^{\mathrm{o} .2}$ & $\begin{array}{c}\text { Dezembro } \\
2017\end{array}$ & p. 66-85 \\
\hline
\end{tabular}


Luiza Helena Hilgert

Por uma Fenomenologia da Linguagem

\section{Introdução $^{1}$}

Como mostrou Edmund Husserl, a intencionalidade inscreve a fenomenologia como filosofia do sentido. $\mathrm{O}$ ato originário da consciência é designar, anunciar, visar, significar em direção a um sentido que ela já porta em si: "todo cogito, toda vivência de consciência (Bewustßtseinerlebnis) ${ }^{2}$, assim podemos dizer também, significa (meint) alguma coisa e, porta em si mesmo, enquanto significado ${ }^{3}$ (Gemeinten), seu respectivo cogitatum" ${ }^{456}$. O cogitatum do qual fala Husserl, não é mero conteúdo cognitivo, racional ou psicológico, tampouco é um objeto intramundano pronto para ser percebido; cogitatum é sentido visado. Para reforçar, Husserl esclarece que “[...] a palavra intencionalidade (Intentionalität) não significa outra coisa que esta propriedade fundamental e geral (allgemeine Grundeigenschaft) da consciência, de ser consciência de algo, da mesma forma que o cogito carrega (tragen) nele mesmo seu cogitatum" ${ }^{\text {"78 }}$. A análise intencional nos faz conceber a relação entre consciência e mundo de uma maneira diferente ${ }^{9}$ : para

\footnotetext{
${ }^{1} \mathrm{O}$ presente artigo apresenta os resultados parciais da minha pesquisa sobre o tema da linguagem em Sartre e Merleau-Ponty, tendo, assim, muito mais a intenção de introduzir e justificar a discussão sobre a linguagem como tema fundamental da fenomenologia que elaborar argumentos conclusivos sobre o que é fenomenologia da linguagem

${ }^{2} \mathrm{O}$ termo alemão Bewusßtseinerlebnis é traduzido em inglês por conscious process, processo consciente; a versão em francês adota a expressão état de conscience, estado de consciência. Em geral, as traduções brasileiras seguem a francesa fazendo uso da mesma tradução por estado de consciência. O termo erlebnis é, no entanto, traduzido frequentemente como vivência ou experiência tanto em francês, quanto em inglês e em português. Erlebnis significa o estado de consciência pessoalmente vivido, ou experenciado, de maneira individual, como um tipo de atividade, evento, processo mental na forma de ato; diferente do termo Erfahrung que significa experiência no sentido comum. Considero uma tradução mais próxima da literal, isto é, vivência, a melhor escolha, neste caso.

${ }^{3}$ No sentido de objeto visado, objeto intencionado. Cf. citação número 12, o uso do verbo Meinen por Paul Ricœur.

${ }^{4}$ Todas as traduções são de minha autoria, feitas a partir do original, salvo indicação. Disponho a citação original em nota de rodapé para verificação, quando julgar necessário. No caso das obras de Husserl e Heidegger, as traduções do alemão são também cotejadas com as traduções existentes em inglês e em francês. A citação traduzida é acompanhada da referência bibliográfica à obra original. A bibliografia completa de todas as obras utilizadas pode ser encontrada em referências.

${ }^{5},[\ldots]$ jedes cogito, jedes Bewußtseinserlebnis, so sagen wir auch, meint irgend etwas und trägt in dieser Weise des Gemeinten in sich selbst sein jeweiliges cogitatum, und jedes tut das in seiner Weise“.

${ }^{6}$ HUSSERL, Edmund. Cartesianische Meditationen und Pariser Vorträge. Den Haag: Martinus Nijhoff, 1950, p. 71.

7 „Bewußtseinserlebnisse nennt man auch intentionale, wobei aber das Wort Intentionalität dann nichts anderes als diese allgemeine Grundeigenschaft des Bewußtseins, Bewußtsein von etwas zu sein, als cogito sein cogitatum in sich zu tragen, bedeutet".

${ }^{8}$ HUSSERL, Edmund. Cartesianische Meditationen und Pariser Vorträge. Den Haag: Martinus Nijhoff, 1950 , p. 72. ${ }^{9}$ Uma explicação pormenorizada da discussão histórica entre idealismo e realismo seria bastante conveniente para resgatar teorias anteriores e, a partir daí, demostrar melhor como a fenomenologia representa uma outra forma de pensar o conhecimento; entretanto, ainda que desejável, essa tarefa extrapolaria os limites da presente pesquisa. Por outro lado, também é importante observar que a fenomenologia significa muito mais que uma nova alternativa ao debate idealismo x realismo. No curso intitulado As ciências do homem e a fenomenologia, Merleau-Ponty, reforça os objetivos da fenomenologia: "O esforço filosófico de Husserl é, com efeito, destinado em todo o seu espírito, a resolver simultaneamente uma crise da filosofia, uma crise das ciências do homem e uma crise das ciências simplesmente, da qual nós ainda não saímos" ("L’effort philosophique de Husserl est en effet destiné dans son esprit à résoudre simultanément une crise de la philosophie, une crise des sciences de l'homme, et une crise des sciences tout court, dont nous ne sommes pas encore sortis"). MERLEAU-PONTY, Maurice. Parcours deux : 1951 - 1961. Paris : Verdier, 2000, p. 49.
}

\begin{tabular}{|c|c|c|c|c|c|}
\hline intuitio & $\begin{array}{c}\text { ISSN } \\
1983-4012\end{array}$ & Porto Alegre & Vol.10- N $^{\circ} .2$ & $\begin{array}{c}\text { Dezembro } \\
2017\end{array}$ & p. 66-85 \\
\hline
\end{tabular}


Luiza Helena Hilgert

Por uma Fenomenologia da Linguagem

a fenomenologia, mundo e consciência não são duas entidades separadas justapostas uma diante da outra, mas se correlacionam de uma maneira co-originária, de forma que a consciência não represente o mundo, e sim abrigue em si um sentido ${ }^{10}$ do mundo no sujeito.

Se a tradicional compreensão da linguagem pelas teorias da representação ameaçaria recolocar a fenomenologia no âmbito da dualidade sujeito versus objeto, é preciso entender que a significação, para a fenomenologia, é tratada de outra maneira. Paul Ricœur, discorrendo sobre a fenomenologia da significação ${ }^{11}$ de Husserl, defende que a questão fundamental da fenomenologia é, justamente, a significação $^{12}$ : $O$ que significa, significar? A pergunta ricœuriana pelo sentido de significar remete à intencionalidade, enquanto ato vazio da consciência a ser preenchido por uma presença; o perguntado da questão não é o que é o sentido, mas como se significa o sentido. De onde vem esse poder de significar? A fenomenologia parte da relação da consciência com as coisas por meio dos signos, da fala, do discurso, do uso disso que Merleau-Ponty chamou de mundo cultural $^{13}$. Porque o ato primeiro da consciência é

\footnotetext{
10 "Consciência é precisamente consciência 'de' alguma coisa; é da sua essência abrigar (bergen) em si um 'sentido', que é, por assim dizer, a quintessência da 'alma', do 'espírito', da 'razão'”. („Bewußtsein ist eben Bewußtfein,von' etwas, es ist sein Wesen, ,Sinn', sozusagen die Quintessenz von ,Seele', ,Geist', ,Vernunft" in sich zu bergen“). HUSSERL, Edmund. „Ideen zu einer reinen Phänomenologie un phänomenologischen Philosophie. Allgemeine Eirgührung in die reine Phänomenologie". In Jahrbuch für Philosophie und phänomenologische Forschung. Halle: Max Niemeyer Verlage, 1913, p. 176, grifo meu.

${ }^{11}$ Cf. Phénoménologie de la signification, RICEUR, Paul. À l'école de la phénoménologie. Paris : Vrin, 2004, pp. 9-
} 12.

12 "É importante observar que a primeira questão da fenomenologia é: o que signfica, significar? Qualquer que seja a importância posteriormente tomada pela descrição da percepção, a fenomenologia parte, não disso que há de mais mudo na operação da consciência, mas da sua relação com as coisas pelos signos tais como os elabora uma cultura falada. O ato primeiro da consciência é de querer dizer, de designar (Meinen); distinguir a significação, entre os outros signos, dissociá-la da palavra, da imagem, elucidar as diversas maneiras segundo as quais uma significação vazia vem a ser preenchida por uma presença intuitiva (qualquer que seja), isso é descrever fenomenologicamente a significação. Este ato vazio de significar não é outra coisa que a intencionalidade. Se a intencionalidade é essa propriadade remarcável, de a consciência ser consciente de..., de escapar-se de si mesma em direção a um outro, $o$ ato de significar contém o essencial da intencionalidade". ("Il est important de remarquer que la première question de la phénoménologie est : que signifie, signifier ? Quelle que soit l'importance prise ultérieurement par la description de la perception, la phénoménologie part, non de ce qu'il y a de plus muet dans l'opération de conscience, mais de sa relation aux choses par les signes, tels que les élabore une culture parlée. L'acte premier de la conscience est de vouloir dire, de désigner (Meinen) ; distinguer la signification, parmi les autres signes, la dissocier du mot, de l'image, élucider les diverses manières dont une signification vide vient à être remplie par une présence intuitive (quelle qu'elle soit), c'est cela décrire, phénoménologiquement la signification. Cet acte vide de signifier n'est pas autre chose que l'intentionnalité. Si l'intentionnalité est cette propriété remarquable, de la conscience d'être conscience de, de s'échapper à soi-même vers un autre, l'acte de signifier contient l'essentiel de l'intentionnalité".) RICEUR, Paul. À l'école de la phénoménologie. Paris : Vrin, 2004, pp. 9-10, grifos meus).

${ }^{13}$ Mundo cultural, mundo espiritual, mundo humano, mundo comum, ou simplesmente cultura, são os principais termos que o autor utiliza para falar desse universo de significados e de criações humanas. Isso não significa, por outro lado, que Merleau-Ponty oponha natureza à cultura, ao contrário, para o filósofo, desde seus primeiros escritos, o homem é simultaneamente e de maneira indistinta um ser natural e cultural: "É impossível supor no homem uma primeira cama de comportamentos ditos 'naturais' e um mundo cultural ou espiritual fabricado. Tudo é fabricado e tudo é natural no homem [...]". ("Il est impossible de superposer chez l'homme une première couche de comportements que l'on appellerait 'naturels' et un monde culturel ou spirituel fabriqué. Tout est fabriqué et tout est naturel chez l'homme [...]”.). MERLEAU-PONTY, Maurice. Phénoménologie de la perception. Paris : Gallimard, 1945, p. 220-221). Em obra posterior, La prose du monde, Merleau-Ponty acentua o papel da linguagem, com seu

\begin{tabular}{|c|c|c|c|c|c|}
\hline intuitio & $\begin{array}{c}\text { ISSN } \\
1983-4012\end{array}$ & Porto Alegre & Vol.10- No.2 & $\begin{array}{c}\text { Dezembro } \\
2017\end{array}$ & p. 66-85 \\
\hline
\end{tabular}


propriamente querer dizer, é importante que a fenomenologia possa elucidar o que significa significar, distinguindo a significação de outros signos e formatos para que se possa desvendar as diversas maneiras que a significação se efetiva a fim de, então, apreender fenomenologicamente o ato originário da significação. Compreender o homem como ser significante é inscrevê-lo como ser de linguagem que capta e atribui sentido às próprias vivências. Assim, o tema da linguagem é fundamentalmente presente na discussão fenomenológica; o estatuto e o grau de relevância podem, no entanto, variar de acordo com cada filósofo.

\section{Husserl e Heidegger}

Precursor da fenomenologia, Edmund Husserl manteve presente o tema da linguagem durante toda a sua trajetória, apesar de, segundo a ótica pontiana, não conservar a mesma concepção ${ }^{14}$. Os textos iniciais, especialmente as Investigações lógicas (1900), propõem a "ideia de uma eidética da linguagem e de uma gramática universal que fixariam as formas de significação indispensáveis a toda linguagem"1516. A linguagem é ali considerada por Husserl como um objeto diante do pensamento que não acompanha a intuitibilidade do objeto e distancia, cada vez mais, mundo sensível e mundo cultural porque a toma como uma mediação não confiável enquanto não adequada à gramática universal ${ }^{17}$. Mais tarde, na Lógica formal e lógica transcendental (1929) e na Origem da geometria (1939), a linguagem aparece como "uma maneira original de visar certos objetos"18 e deixa, nesse segundo momento, de ser mediação não confiável para tornar-se condição transcendental enquanto estrutura do mundo vivido (Lebenswelt). Segundo Jolgrilberg (2002), com a noção de Lebenswelt, Husserl não opera somente uma reconciliação entre fenomenologia e História, mas radicaliza e modifica completamente a compreensão da linguagem

conjunto de significados historicamente estabelecidos: “[...] nós o chamamos mundo cultural e chamamos palavra o poder que temos de fazer servir certas coisas convenientemente organizadas - o preto e o branco, o som da voz, os movimentos da mão, - para destacar, diferenciar, conquistar, acumular as significações que se mantêm no horizonte do mundo sensível, ou ainda, insuflar na opacidade do sensível este vazio que o tornará transparente, mas que ele próprio, como o ar soprado na garrafa, nunca é sem alguma realidade substancial”. (“[...] nous l'appelons monde culturel et nous appelons parole le pouvoir que nous avons de faire servir certaines choses convenablement organisées, - le noir et le blanc, le son de la voix, les mouvements de la main, - à mettre en relief, à différencier, à conquérir, à thésauriser les significations qui traînent à l'horizon du monde sensible, ou encore d'insuffler dans l'opacité du sensible ce vide qui le rendra transparent, mais qui lui-même, comme l'air soufflé dans la bouteille, n'est jamais sans quelque réalité substantielle",) MERLEAU-PONTY, Maurice. La prose du monde. Texte établi et présenté par Claude Lefort. Paris : Gallimard,1969, p. 199).

${ }_{15}^{14}$ Cf. MERLEAU-PONTY, Maurice. Signes. Paris : Gallimard, 1960, pp. 105 e ss.

15 "l'idée d'une eidétique du langage et d'une grammaire universelle qui fixeraient les formes de signification indispensables à tout langage".

${ }^{16}$ MERLEAU-PONTY, Maurice. Signes. Paris : Gallimard, 1960, p. 105.

${ }^{17}$ Sobre o tratamento do problema da linguagem dado por Husserl, acompanho a explicação de Rui Jolgrilberg, no artigo $O$ último Husserl e a linguagem. A referência completa é apresentada em referências.

${ }^{18}$ MERLEAU-PONTY, Maurice. Signes. Paris : Gallimard, 1960, p. 106.

\begin{tabular}{|c|c|l|l|c|c|}
\hline intuitio & $\begin{array}{c}\text { ISSN } \\
1983-4012\end{array}$ & Porto Alegre & Vol.10- $\mathrm{N}^{\circ} .2$ & $\begin{array}{c}\text { Dezembro } \\
2017\end{array}$ & p. 66-85 \\
\hline
\end{tabular}


como portadora de horizontes originários de significação, a medida em que concebe o mundo vivido como o novo solo transcendental da fenomenologia.

Herdeiro da fenomenologia husserliana, Martin Heidegger se opõe à compreensão de seu mestre que funda a linguagem em atos intencionais e intuições ${ }^{19}$. Na obra fundamental de Heidegger, Ser e tempo $(1936)^{20}$, o autor aponta a pergunta pelo sentido de ser com o tema fundamental da sua obra ${ }^{21}$. Ainda que a linguagem não seja o tema central de $\operatorname{Ser}$ e tempo ${ }^{22}$, a pergunta pelo sentido de ser exige uma linguagem livre dos preconceitos da metafísica tradicional ${ }^{23}$. O quinto capítulo da obra ${ }^{24}$ informa, já no início, o objetivo de fornecer "a explicação do ser-em como tal, isto é, do 'aí",25, constituído por dois existenciários: a afecção (Befindlichkeit) e o entender (Verstehen), que são, por sua vez "originalmente e igualmente determinados pela fala (Rede)"26. Para o Heidegger de Ser e tempo, "O fundamento ontológico-existenciário da linguagem é a fala" ${ }^{27}$, isso significa que existe linguagem na medida em que existe a fala, não há anterioridade de uma sobre a outra; isso também significa que a fala (Rede) não é um

${ }^{19}$ Teoria explicitada, principalmente, nas Investigações lógicas.

${ }^{20}$ Cito aqui a partir da versão bilíngue de Fausto Castilho, que fez uso da edição de 1977, conhecida como exemplar da cabana.

21 “A preparação concreta da questão segundo o sentido do ser é a intenção do seguinte ensaio". (HEIDEGGER, 1977, p.1; 2012, p. 31). "Die konkrete Ausarbeitung der Frage nach dem Sinn von 'Sein' ist die Absicht der folgenden Abhandlung“.

${ }^{22}$ A importância do tema da linguagem é confessada no texto De uma conversa sobre a linguagem entre um japonês e um pensador, texto em forma de diálogo em que Heidegger descreve o encontro que tivera com o germanista japonês Tomio Tezuka, no ano de 1954, na cidade de Friburgo, publicado em 1959 no livro A caminho da linguagem. Observa-se, com efeito, a presença do tema da linguagem desde seu trabalho monográfico de habilitação sobre a teoria da significação de Duns Scotus, intitulado A doutrina das categorias e da significação de Duns Scotus (1915) (Die Kategorien und Bedeutungslehre des Duns Scotus), utilizo aqui a publicação de 1972. Em geral, concorda-se que o momento conhecido como Kehre, a viragem do pensamento heideggeriano marca uma mudança de perspectiva no tratamento da relação entre a linguagem e o ser. É na famosa Carta sobre o humanismo (1947) (Brief über den Humanismus) que Heidegger assinala a divisão dos seus escritos tomando como referência o ano de 1930 (cf. Heidegger, Martin. Brief über den Humanismus. Frankfurt am Main: Vittorio Klostermann, 1947, p. 17). É, sobretudo, a partir da linguagem (no sentido que Françoise Dastur utiliza em seu livro Heidegger: la question du logos que Heidegger questiona o ser e a verdade do ser também na obra A caminho da linguagem. Cf. DASTUR, Françoise. Heidegger: la question du logos. Paris: Vrin, 2007.

${ }^{23}$ Veja-se, por exemplo, o empenho de Heidegger no $\$ 7$ O método fenomenológico da investigação, em retornar aos termos gregos de fenômeno e de logos para "limpá-los" do uso feito pela tradição. Apresento um estudo do método fenomenológico em Ser e tempo no artigo: Fenomenologia como ontologia: um estudo a partir de Sein und Zeit (no prelo).

${ }^{24}$ Intitulado $O$ ser como tal. Cf. HEIDEGGER, Marting. Ser e tempo. Edição em alemão e português (1977). Tradução e organização de Fausto Castilho. Col. Multilíngues de Filosofia Unicamp. Campinas/SP: Editora da Unicamp; Petrópolis/RJ: Editora Vozes, 2012, pp. 130-181.

${ }^{25}$ HEIDEGGER, Marting. Ser e tempo. Edição em alemão e português (1977). Tradução e organização de Fausto Castilho. Col. Multilíngues de Filosofia Unicamp. Campinas/SP: Editora da Unicamp; Petrópolis/RJ: Editora Vozes, 2012, p. 133.

${ }^{26}$ HEIDEGGER, Marting. Ser e tempo. Edição em alemão e português (1977). Tradução e organização de Fausto Castilho. Col. Multilíngues de Filosofia Unicamp. Campinas/SP: Editora da Unicamp; Petrópolis/RJ: Editora Vozes, 2012, p. 133.

${ }^{27}$ HEIDEGGER, Marting. Ser e tempo. Edição em alemão e português (1977). Tradução e organização de Fausto Castilho. Col. Multilíngues de Filosofia Unicamp. Campinas/SP: Editora da Unicamp; Petrópolis/RJ: Editora Vozes, 2012, p. 161.

\begin{tabular}{|c|c|l|l|c|c|}
\hline intuitio & $\begin{array}{c}\text { ISSN } \\
1983-4012\end{array}$ & Porto Alegre & Vol.10- $\mathrm{N}^{\circ} .2$ & $\begin{array}{c}\text { Dezembro } \\
2017\end{array}$ & p. 66-85 \\
\hline
\end{tabular}


atributo do Dasein, mas condição de possibilidade de toda comunicação, de toda linguagem e que, de fato, só existe linguagem porque existe a fala ${ }^{28}$. Heidegger concebe a fala, com efeito, como a articulação entre o Befindlichkeit e o Verstehen justamente porque concebe o Dasein com dimensão de facticidade, como ser-no-mundo, como ser-em-situação.

O campo aberto pela fenomenologia permitiu, legitimamente, uma infinidade de possibilidades na compreensão da linguagem, de onde novos outros caminhos foram trilhados e continuam se expandindo atualmente. A concepção heideggeriana da linguagem aliada aos postulados de Husserl, representam a base fenomenológica para a discussão do problema da linguagem desenvolvida por Sartre e por MerleauPonty. Sem que o problema da verdade e a pergunta pelo sentido do ser tenham sido esquecidos pela fenomenologia francesa, a reflexão merleau-pontiana pensou a linguagem conjuntamente com o estruturalismo de Ferdinand de Saussure e com a pintura; ao passo que Sartre escreveu uma teoria literária na qual resgatou a história da literatura francesa em relação com a sociedade alertando sobre o poder da palavra. A ontofenomenologia de Sartre não deixou de ser uma pergunta pelo sentido da existência humana que encontra na linguagem - mais especificamente na prosa - uma forma de desvelamento, à medida que A prosa do mundo (1969) junto com O visível e o invisível (1964) representam a tentativa merleau-pontiana de dar conta da relação entre linguagem e verdade ${ }^{29}$. Creio podermos dizer que a fenomenologia francesa ganhou em sensibilidade e alargamento do tema na discussão sobre o problema da linguagem se comparada às Investigações lógicas e $A$ caminho da linguagem, sem que isso tenha significado perda de rigor e profundidade de questionamento característicos das citadas obras alemãs.

\section{Merleau-Ponty e Sartre: sobre significação, palavra e fala}

Propondo um retorno às teses e ao movimento do pensamento husserliano, Merleau-Ponty ${ }^{30}$ concorda que a versatilidade da língua possa gerar a impressão de posse de um instrumento capaz de dar destino a todos os fins, de dizer tudo que se deve dizer e, como consequência dessa sensação, são criados

\footnotetext{
${ }^{28}$ Entendida, portanto, como condição de possibilidade de todo e qualquer discurso.

${ }^{29}$ Cf. MERLEAU-PONTY, Maurice. «Un inédit de Maurice Merleau-Ponty ». In : Revue de Métaphysique et de Morale, 67e Année, No. 4, Octobre-Décembre 1962, pp. 401-409.

30 "Este problema permite melhor que outro de interrogar a fenomenologia e, não somente de repetir Husserl, mas de recomeçar seu esforço, de retomar, muito mais que suas teses, o movimento da sua reflexão". ("Ce problème permet donc mieux qu'un autre d'interroger la phénoménologie et, non seulement de répéter Husserl, mais de recommencer son effort, de reprendre, plutôt que ses thèses, le mouvement de sa réflexion".) MERLEAU-PONTY, Maurice. Signes. Paris : Gallimard, 1960, p. 105. Importante observar que Merleau-Ponty realizou, de fato, uma retomada do pensamento husserliano sobre a linguagem e acompanhou de perto o movimento da sua reflexão; por isso, estudar o estatuto da linguagem em Merleau-Ponty implica refazer junto com ele o caminho do movimento reflexivo husserliano sobre a linguagem.
}

\begin{tabular}{|c|c|c|c|c|c|}
\hline intuitio & $\begin{array}{c}\text { ISSN } \\
1983-4012\end{array}$ & Porto Alegre & Vol.10- $\mathrm{N}^{\circ} .2$ & $\begin{array}{c}\text { Dezembro } \\
2017\end{array}$ & p. 66-85 \\
\hline
\end{tabular}


os "mitos próprios da linguagem [e o] sonho de uma língua verdadeiramente fundada na "natureza das coisas' [de onde] os termos e as relações elementares permitiriam por simples combinação, compor toda

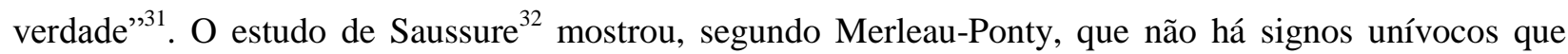
correspondam às ideias de forma clara e distinta, porque nem a palavra, nem as formas de uma língua, contêm a significação, mas somente há clareza no contexto de um discurso, no interior de uma língua, porque uma palavra depende da outra e da situação do discurso para fazer sentido. Segundo MerleauPonty, "a verdade é feita de significações abertas"33.

Em $O$ que é literatura? (1948), Sartre enumera algumas críticas ${ }^{34}$ recebidas em função do conceito de literatura engajada que vinha apresentando em conferências e entrevistas. Fundamentalmente, as críticas refletiam uma má compreensão do público do conceito de engajamento, o que exigiu um esforço por parte do filósofo na direção de examinar a arte da escrita sem pré-julgamentos e pré-conceitos, explicando as três questões fundamentais para uma teoria da literatura: Que é escrever? Por que se escreve? Para quem se escreve?. De maneira irônica, seus opositores interrogavam se a poesia, a música e a pintura também deveriam ser "engajadas". O primeiro capítulo que se dedica à questão: $O$ que é escrever?, inicia pela negação da reivindicação do engajamento das outras artes. Muito mais que querer elevar a prosa literária a um nível acima das outras artes, a recusa de Sartre em exigir o engajamento de todas as artes significa o reconhecimento por parte do filósofo da especificidade de cada gênero artístico, que não aglomera os gêneros artísticos sob um mesmo registro. Sartre é um escritor de romances, contos e peças de teatro; ainda que se interesse por Mallarmé, Giacometti, Tintoretto, cinema e jazz, ele o faz de forma diferente, de fora, como um observador, e não de dentro como é o caso da sua relação com a escrita. Os críticos que se opõem ao conceito de literatura engajada se valem de um argumento paralelista, segundo o qual se não se exige o engajamento das outras artes, então a ideia de literatura engajada é um engodo, porque entendem que a regra deve valer para todas as formas de arte. Sartre não compactua com esse paralelismo entre as artes e afirma que é preciso considerar cada gênero artístico singularmente, conforme suas características e aspectos próprios. Se outras artes são passiveis de engajamento ou não, é uma outra questão. O objetivo sartriano é teorizar acerca do escritor de prosa engajado e da prosa literária

\footnotetext{
${ }^{31}$ MERLEAU-PONTY, Maurice. Parcours deux : 1951 - 1961. Paris : Verdier, 2000, pp. 29-30.

${ }^{32} \mathrm{O}$ principal trabalho de Sausurre que Merleau-Ponty conhecia é: SAUSSURE, Ferdiand de. Cours de linguistique générale. Paris: Payot, 2005

${ }^{33}$ MERLEAU-PONTY, Maurice. Parcours deux : 1951 - 1961. Paris : Verdier, 2000, p. 31.

${ }^{34}$ Um resumo das críticas recebidas por Sartre é por ele assim enunciado: "Se você deseja engajar-se, escreve um jovem imbecil, o que espera para inscrever-se no P.C.? [...] 'Os piores artistas são os mais engajados' [...]. 'Você quer assassinar a literatura; o desprezo pelas Belas Artes se instale de maneira insolente em sua revista'. [...] Os irônicos piscam o olho: ‘E a poesia? E a pintura? E a música? Quer engajá-las também?"”. (“'Si vous voulez vous engager, écrit un jeune imbécile, qu'attendez-vous pour vous inscrire au P. C?'[...] 'Les plus mauvais artistes sont les plus engagés' [...]. 'Vous voulez assassiner la littérature; le mépris des Belles-Lettres s'étale insolemment dans votre revue'. [...] Des malins clignent de l'oeil: 'Et la poésie ? Et la peinture ? Et la musique ? Est-ce que vous voulez aussi les engager ?"' (SARTRE, Situations II. Paris : Gallimard, 1948, p. 57).
}

\begin{tabular}{|c|c|c|c|c|c|}
\hline intuitio & $\begin{array}{c}\text { ISSN } \\
1983-4012\end{array}$ & Porto Alegre & Vol.10 - No.2 & $\begin{array}{c}\text { Dezembro } \\
2017\end{array}$ & p. 66-85 \\
\hline
\end{tabular}


engajada $^{35}$. À revelia das intenções iniciais de Sartre, a obra $O$ que é literatura?, além de uma teoria literária da escrita engajada, desemboca numa teoria sobre a linguagem porque ali estão presentes, como fio condutor de toda a discussão, a própria concepção do filósofo de sentido, significação, expressividade e comunicação.

A principal distinção, segundo Sartre, entre a prosa e as outras artes, é que a prosa faz uso de signos: "As notas, as cores, as formas não são signos, não reenviam a nada que lhes seja exterior"36 37 . Para Sartre, a prosa é a única entre as artes a fazer uso de signos, mas reconhece que não é a única a ter sentido. $\mathrm{O}$ autor cita Merleau-Ponty ${ }^{38}$ para reforçar a ideia de que não há qualidade ou sensação tão pura que não seja penetrada de significação. Na concepção sartriana, um pintor ou um músico entendem a cor ou o som como objetos de um grau superior, cor-objeto, som-objeto, que o artista vai transportar para a tela transformando a cor-objeto em objeto-imaginário, jamais em linguagem. $\mathrm{O}$ artista não deseja traçar signos na sua tela, ele quer criar uma coisa, ou seja, o artista não quer que sua obra possua uma significação específica, intrínseca, definitiva e reconhecível, que reenvie nomeadamente a outro objeto, como faz um signo, ele quer criar a coisa-cólera, a coisa-ódio e assim por diante. Sartre não nega às artes significado e expressão, mas defende que para a música e a pintura, por exemplo, é de modo diferente da linguagem literária.

A questão-chave consiste, com efeito, na concepção de significado e sentido: as palavras, na prosa literária, podem ser substituídas por outras de igual sentido e a ideia transmitida pela obra se mantém; na pintura e na música, por outro lado, não se alteram pinceladas, cores ou melodias sem modificar o produto da arte. Isso porque as palavras, os signos, remetem a outro objeto além deles, significam para além deles, enquanto as outras artes são já em si objetos de significado, como um canto de dor é a própria dor, as cores do céu de $O$ grito são o desespero e a angústia. Quando escritor escreve sobre casas, exemplifica Sartre, ele pode dirigir o leitor a enxergar ali as injustiças sociais e provocar indignação; "já o pintor é

35 "Mas aqueles que desejam demonstrar a absurdidade de uma teoria literária mostrando que ela é inaplicável à música devem provar, antes de tudo, que as artes são paralelas. Ora, esse paralelismo não existe. [...] não é apenas a forma que as diferencia, mas a matéria; trabalhar com cores e sons é uma coisa, exprimir-se por palavras é outra”. ("Mais ceux qui veulent faire voir l'absurdité d'une théorie littéraire en montrant qu'elle est inapplicable a la musique doivent prouver d'abord que les arts sont parallèles. Or ce parallélisme n'existe pas. [...] n'est pas seulement la forme qui différencie, mais aussi la matière; et c'est une chose que de travailler sur des couleurs et des sons, c'en est une autre de s'exprimer par des mots".) (SARTRE, Jean-Paul. Situations II. Paris : Gallimard, 1948, pp. 59-60).

36 "Les notes, les couleurs, les formes ne sont pas de signes, eles ne renvoient à rien qui leur soit extérieur".

${ }^{37}$ SARTRE, Jean-Paul. Situations II. Paris : Gallimard, 1948, p. 60.

38 "Naturalmente é impossível reduzi-las estritamente a elas mesmas e à ideia de um som puro, por exemplo, é uma abstração: não há, Merleau-Ponty demonstrou em Phénoménologie de la perception, qualidade ou sensação tão desenraizada que não sejam penetradas de significação". ("Bien entendu, il est tout à fait impossible de les réduire strictement à elles-mêmes et l'idée d'un son pur, par exemple, est une abstraction : il n'y a, Merleau-Ponty l'a bien montré dans la Phénoménologie de la perception, de qualité ou de sensation si dépouillées qu'elles ne soient pénétrées de signification”). SARTRE, Jean-Paul. Situations II. Paris : Gallimard, 1948, p. 60.

\begin{tabular}{|c|c|l|l|c|c|}
\hline intuitio & $\begin{array}{c}\text { ISSN } \\
1983-4012\end{array}$ & Porto Alegre & Vol.10- $\mathrm{N}^{\mathrm{o} .2}$ & $\begin{array}{c}\text { Dezembro } \\
2017\end{array}$ & p. 66-85 \\
\hline
\end{tabular}


mudo"39: se ele pinta um casebre, nele estão contidas diferentes interpretações à escolha do espectador, tanto a simplicidade do casebre pode ser interpretada como um valor ou como a marca de injustiças, independentemente da vontade do artista. Um casebre pintado sob uma tela nunca será a priori símbolo da miséria, para isso o casebre deveria ser signo; na tela, o casebre é coisa. Não se exige, portanto, da música ou da pintura que se engajem, porque não se pintam signos, não se transformam signos em música; é o escritor que lida com significados, o império dos signos é a prosa ${ }^{40}$. Assim como o pintor e o músico, o poeta adota a atitude artística segundo a qual as palavras são coisas, instituições, objetos e não signos. Ele não utiliza as palavras como o prosador $^{41}$ : ele se afastou da linguagem-instrumento, o poeta toma a linguagem do avesso ${ }^{42}$.

Tudo isso coloca o poeta numa relação diferente com a palavra: para o poeta, as palavras possuem características e aspectos que representam a significação muito mais que a exprimem. Na concepção de Sartre, a palavra do poema, a cor do quadro, o som, a melodia, não são mais meramente um significado, são objetos, produtos da $\operatorname{arte}^{43}$. Por isso, não se exige engajamento da poesia, da música, ou da pintura, pois o artista realiza um tipo de atividade que consiste justamente em convidar o leitor/espectador a se desembaraçar da condição humana, a ficar ao lado de deus e olhar a linguagem do avesso.

${ }^{39}$ SARTRE, Jean-Paul. Situations II. Paris : Gallimard, 1948, p. 62.

${ }^{40}$ Cf. SARTRE, Jean-Paul. Situations II. Paris : Gallimard, 1948, p. 63.

41 "A prosa é utilitária por essência; eu definiria o prosador como um homem que se serve das palavras. [...] $\mathrm{O}$ escritor é um falador: ele designa, demonstra, ordena, recusa, interpela, suplica, insulta, persuade, insinua. [...] A arte da prosa se exerce sobre pelo discurso, sua matéria é, naturalmente, signficante: isso quer dizer que as palavras não são os objetos, mas designações de objetos". ("La prose est utilitaire par essence ; je définirais volontiers le prosateur comme un homme qui se sert des mots. [...] L'écrivain est un parleur : il désigne, démontre, ordonne, refuse, interpelle, supplie, insulte, persuade, insinue. [...] L'art de la prose s'exerce sur le discours, sa matière est naturellement signifiante : c'est-à-dire que les mots ne sont pas d'abord des objets, mais des désignations d'objets"). SARTRE, Jean-Paul. Situations II. Paris : Gallimard, 1948, p. 70.

42 "Mas se ele se prende às palavras, como o pintor faz com as cores e o músico com os sons, isso não quer dizer que elas tenham perdido toda a significação [...]. Impregnada pela palavra, absorta por sua sonoridade ou pelo seu aspecto visual, encorpada, degradada, ela [a signficação] é coisa, ela também, incriada, eterna; para o poeta, a linguagem é uma estrutura do mundo exterior. [...] O poeta está fora da linguagem, ele vê as palavras pelo avesso, como se não pertencessem à condição humana. [...] Não sabendo se servir dela como signo de um aspecto do mundo, ele vê na palavra a imagem de um desses aspectos". ("Mais s'il s'arrête aux mots, comme le peintre fait aux couleurs et le musicien aux sons, cela ne veut pas dire qu'ils aient perdu toute signification [...]. Coulée dans le mot, absorbée par sa sonorité ou par son aspect visuel, épaissie, dégradée, elle [a significação] est chose, elle aussi, incréée, éternelle ; pour le poète, le langage est une structure du monde extérieur. [...] Le poète est hors du langage, il voit les mots à l'envers, comme s'il n'appartenait pas à la condition humaine. [...] Faute de savoir s'en servir comme signe d'un aspect du monde, il voit dans le mot l'image d'un de ces aspects"). SARTRE, Jean-Paul. Situations II. Paris : Gallimard, 1948, pp. 65-66.

43 "Sem dúvida a emoção, mesmo a paixão - e por que não, a colera, a indignação social, o ódio político - estão na origem do poema. Mas não se exprimem, como em um panfleto ou em uma confissão. [...] A emoção se tornou coisa, tem agora a opacidade das coisas; está turvada pelas propriedades ambíguas dos vocábulos nos quais foi encerrada. E sobretudo há sempre muito mais, em cada frase [...]". ("Sans doute l'émotion, la passion même - et pourquoi pas la colère, l'indignation sociale, la haine politique — sont à l'origine du poème. Mais elles ne s'y expriment pas, comme dans un pamphlet ou dans une confession. [...] L'émotion est devenue chose, elle a maintenant l'opacité des choses; elle est brouillée par les propriétés ambiguës des vocables où on l'a enfermée".). SARTRE, Jean-Paul. Situations II. Paris : Gallimard, 1948, p. 69).

\begin{tabular}{|c|c|l|l|c|c|}
\hline intuitio & $\begin{array}{c}\text { ISSN } \\
1983-4012\end{array}$ & Porto Alegre & Vol.10- $\mathrm{N}^{\circ} .2$ & $\begin{array}{c}\text { Dezembro } \\
2017\end{array}$ & p. 66-85 \\
\hline
\end{tabular}


Merleau-Ponty utiliza justamente o termo do avesso quando fala da linguagem como expressão de um significado novo: "Como o tecelão, portanto, o escritor trabalha do avesso: ele lida somente com a linguagem e é assim que, de repente, se encontra rodeado de sentido"44 45 . Trabalhar a linguagem do seu lado avesso significa justamente fazê-lo a partir de dentro, dos seus meandros. Em texto de 1952, dedicado a Sartre, A linguagem indireta e as vozes do silêncio, Merleau-Ponty apresenta a ideia de que a arte é um tipo de linguagem ${ }^{46}$ e em todo tipo de linguagem estão implícitos ambiguidade e silêncio. Para expressar um significado novo, o escritor precisa, justamente, lidar com "o avesso da linguagem": antes de usar as palavras para designar algo, um pensamento externo, o escritor habita a linguagem, lida com ela, e deste modo, de dentro dela que é o lado avesso, constrói um significado. Não é copiando um pensamento que a linguagem significa; ao contrário, na expressão criadora o sentido é oblíquo, se insinua entre as palavras, suscitando através da linguagem um novo significado. Merleau-Ponty distingue o uso empírico do uso criativo da linguagem ${ }^{47}$, o primeiro diz respeito ao seu uso secundário, traduz um pensamento já adquirido; enquanto o segundo se refere ao uso originário, faz a linguagem existir, é a própria apropriação do pensamento.

Para Merleau-Ponty, para compreender fundamentalmente a linguagem e a expressividade, o estudo da arte, especialmente o da pintura, não deve ser subestimado pelos escritores de prosa literária ${ }^{48}$. O que caracteriza a expressividade artística como potência significante é a inerência do sentido ao sensível: "O sentido impregna o quadro muito mais que o quadro o exprime" ${ }^{50}$. Ponty parece concordar com a crítica de Sartre ao paralelismo ao aceitar que cada gênero artístico tem uma potência expressiva singular; no caso da pintura, a expressividade é de forma pictural: o quadro não é um sistema de signos, não se expressa por frases, palavras, pontuação, mas, se tomado no seu conjunto, como obra de arte, como objeto, o quadro fala, dele deriva um sentido aderente, um sentido total. O estudo da pintura como linguagem é legitimado e chega a ser privilegiado porque, segundo o filósofo, "evidencia um sentido perceptivo, cativo da configuração visível [...]; pois talvez nos faça descobrir sob a linguagem falada uma

\footnotetext{
${ }^{44} 44$ "Comme le tisserand donc, l'écrivain travaille à l'envers : il n'a affaire qu'au langage, et c'est ainsi que soudain il se trouve environné de sens".

${ }^{45}$ MERLEAU-PONTY, Maurice. Signes. Paris : Gallimard, 1960, p. 56, grifo meu.

${ }^{46}$ Merleau-Ponty cita Malraux como precursor da ideia de que a pintura fala ao seu modo: "Malraux observe que la peinture et le langage ne sont comparables que lors-qu'on les a détachés de ce qu'ils « représentent » pour les réunir sous la catégorie de l'expression créatrice. C'est alors qu'ils se reconnaissent l'un l'autre comme deux figures de la même tentative" (MERLEAU-PONTY, Signes. Paris : Gallimard, 1960, p. 59).

${ }^{47}$ Cf. MERLEAU-PONTY, Maurice. La prose du monde. Texte établi et présenté par Claude Lefort. Paris : Gallimard, 1969, p. 56.

${ }^{48}$ Numa clara referência ao posicionamento de Sartre, Merleau-Ponty declara: "Il ne faut pas ici que les écrivains sous-estiment le travail, l'étude du peintre, cet effort si semblable à un effort de pensée et qui permet de parler d'un langage de la peinture" (MERLEAU-PONTY, Maurice. La prose du monde. Texte établi et présenté par Claude Lefort. Paris : Gallimard, 1969, p. 69).

49 "Le sens imprègne le tableau plutôt que le tableau ne l'exprime".

${ }^{50}$ MERLEAU-PONTY, Maurice. Signes. Paris : Gallimard, 1960, p. 69.
}

\begin{tabular}{|c|c|c|c|c|c|}
\hline intuitio & $\begin{array}{c}\text { ISSN } \\
1983-4012\end{array}$ & Porto Alegre & Vol.10- $\mathrm{N}^{\circ} .2$ & $\begin{array}{c}\text { Dezembro } \\
2017\end{array}$ & p. 66-85 \\
\hline
\end{tabular}


linguagem operante, cujas palavras vivem de uma vida mal conhecida $[\ldots]^{, 51}$.. Com isso, o autor defende que essa perspectiva beneficia não somente o estudo da pintura, mas, sobretudo, o da linguagem. Em outras palavras, a pintura nos ensina sobre a linguagem e não perde nada em relação ao estudo da linguagem via prosa literária: "Um romance exprime tacitamente assim como um quadro. Pode-se contar o tema do romance como o do quadro" 5253.

O estudo dos textos de Merleau-Ponty permite uma compreensão da linguagem de forma bastante abrangente, a linguagem é considerada como operação expressiva [opération expressive $]^{54}$, potência falante [puissance parlante $]^{55}$, potência significante $\left[\right.$ puissance signifiante] ${ }^{56}$, expressão primordial [expression primordiale $]^{57}$, para citar apenas alguns termos. A expressão é realizada pelo sujeito falante por uma intenção significante, mas essa operação é mais complexa que aparenta porque a operação expressiva é inicialmente "vazia de intenção" "58: o sujeito falante só conhece a sua intenção na fala, falando, de tal maneira que são as palavras, o discurso, que ensinam o pensamento. Antes da operação expressiva, antes da fala, o pensamento era apenas uma certa inquietude na qual o sentido futuro se antecipava de maneira ausente. A expressão, segundo Merleau-Ponty, é uma descoberta de si, isto é, da consciência descobrindo suas próprias intenções: exprimir é tomar consciência, aquele que fala não dá a conhecer somente para os outros, ele exprime para saber ele próprio o que deseja ${ }^{59}$. O sujeito, se é que podemos falar com segurança em sujeito aqui, não é totalmente dono, mestre, senhor da própria intenção significante.

A reflexão sobre a pintura, segundo Merleau-Ponty, reconduz a linguagem ao seu fenômeno originário, a saber, o de captar, tomar, perceber o nascimento do sentido enquanto tal, no momento em que se constitui como tal. Moutinho ${ }^{60}$ chamou esse processo de procura pela gênese do sentido, atividade que exige a realização de uma fenomenologia da fala: devemos olhar para a linguagem como um surdo olha os que falam, como aqueles que ouvem uma língua desconhecida, vê-la como uma linguagem silenciosa e

\footnotetext{
${ }^{51}$ MERLEAU-PONTY, Maurice. Signes. Paris : Gallimard, 1960, p. 95.

52 "Un roman exprime tacitement comme un tableau. On peut raconter le sujet du roman comme celui du tableau".

${ }^{53}$ MERLEAU-PONTY, Maurice. Signes. Paris : Gallimard, 1960, p. 96.

${ }^{54}$ Sur la phénoménologie du langage, pp. 113.

${ }^{55}$ L'homme et l'adversité, p. 295 ; Sur la phénoménologie du langage, p. 110.

${ }^{56}$ Sur la phénoménologie du langage, p. 116.

${ }^{57}$ La prose du monde, p. 110, 206.

${ }^{58}$ Cf. MERLEAU-PONTY, Maurice. Signes. Paris : Gallimard, 1960, p. 112.

59 "Exprimer, pour le sujet parlant, c'est prendre conscience ; il n'exprime pas seulement pour les autres, il exprime pour savoir lui-même ce qu'il vise" (MERLEAU-PONTY, Maurice. Signes. Paris : Gallimard, 1960, p. 113).

59 MOUTINHO, Luiz Damon Santos. Razão e experiência. Ensaio sobre Merleau-Ponty. Coleção Biblioteca de Filosofia. Rio de Janeiro : UNESP, 2006, p. 285.

${ }^{60}$ MOUTINHO, Luiz Damon Santos. Razão e experiência. Ensaio sobre Merleau-Ponty. Coleção Biblioteca de Filosofia. Rio de Janeiro : UNESP, 2006, p. 285.
}

\begin{tabular}{|c|c|c|c|c|c|}
\hline intuitio & $\begin{array}{c}\text { ISSN } \\
1983-4012\end{array}$ & Porto Alegre & Vol.10- $\mathrm{N}^{\circ} .2$ & $\begin{array}{c}\text { Dezembro } \\
2017\end{array}$ & p. 66-85 \\
\hline
\end{tabular}


perceber as vozes do silêncio ${ }^{61}$. Como dito logo no início, conhecer o ato originário da consciência: o ato de significar. $\mathrm{O}$ estudo da pintura funcionaria, nesse sentido, como uma forma de redução fenomenológica da atividade linguística, da atividade expressiva, colocando entre parênteses toda fala, toda palavra, para se alcançar a essência de expressão, ou a gênese do sentido.

Além de Merleau-Ponty e Sartre ${ }^{62}$ herdarem a tradição fenomenológica alemã e terem se tornado expoentes da fenomenologia francesa, partilharam da descoberta da significação como mediação entre homem e mundo, entenderam que a fenomenologia é mais que um método: é uma grande teoria da significação, uma grande teoria sobre a expressividade, uma grande teoria do sentido, uma grande teoria da linguagem. Nesse sentido, pode-se perceber o impacto das reflexões fenomenológicas sobre o problema da linguagem das filosofias de Jean-Paul Sartre e de Maurice Merleau-Ponty em diálogo com seus predecessores - Husserl e Heidegger -, na produção fenomenológica nos dias de hoje ${ }^{63}$. Trata-se de ao mesmo tempo reler as teorias de Husserl e Heidegger em conjunto e contra Sartre e Merleau-Ponty, a fim de compreender em que medida cada um dos alemães os influencia, em que medida se distanciam dos predecessores e em que medida os criticam. Os textos tardios de Merleau-Ponty, assim como aconteceu com o Heidegger dos anos '20, se distanciam significativamente da fenomenologia como método e se dirigem à ontologia, aproximando as influências recebidas de Heidegger, com a noção de Dasein e de Husserl, após a Lebenswelt. O caso de Sartre é um pouco diferente, pois o filósofo já parte da fenomenologia como ontologia ${ }^{64}$ e, com a evolução do seu pensamento, radicaliza a historicidade presente em Heidegger e a noção de Lebenswelt husserliana e termina se aproximando do marxismo. Para pensar a

\footnotetext{
61 "Si nous voulons comprendre le langage dans son opération d'origine il nous faut feindre de n'avoir jamais parlé, le soumettre à une réduction sans laquelle il nous échapperait encore en nous reconduisant à ce qu'il nous signifie, le regarder comme les sourds regardent ceux qui parlent, comparer l'art du langage aux autres arts de l'expression, tenter de le voir comme l'un de ces arts muets. Il se peut que le sens du langage ait un privilège décisif, mais c'est en essayant le parallèle que nous apercevrons ce qui le rend peut-être impossible à la fin. Commençons par comprendre qu'il y a un langage tacite et que la peinture parle à sa façon". (MERLEAU-PONTY, Maurice. Signes. Paris : Gallimard, pp. 58-59).

${ }^{62}$ Como é sabido, a ligação entre os dois filósofos começa como amizade e afinidade política e filosófica, é rompida justamente por divergências políticas e filosóficas, terminando, inesperadamente, com a morte prematura do autor de Fenomenologia da percepção. Impossível desvincular o estudo da filosofia da biografia desses dois mestres franceses. No honesto e emocionante texto de Sartre, Merleau-Ponty, é lembrado o solo filosófico que fora comum aos dois: "Futiles et sérieux, nos maîtres ignoraient l'Histoire ; ils répondaient que ces questions ne se posaient pas" (SARTRE, Situations IV. Paris : Gallimard, 1964, p. 191). Tendo aprendido que buscar as condições de possibilidade da História é superior a lutar contra as injustiças históricas, bastaram-lhes poucos anos para abandonar esse "pensée de survol" (Idem). Em diferentes momentos, aquilo que unia era também o que distanciava: "Husserl devenait à la fois notre distance et notre amitié. Sur ce terrain nous n'étions, comme Merleau l'a bien dit à propos du langage, que "des différences sans termes ou plutôt des termes engendrés par les différences qui apparaissent entre eux" (Situations IV. Paris : Gallimard, 1964, p. 194). Oriundos da mesma classe, seguindo os mesmos mestres, lutando ao mesmo lado na guerra, perceberam o lugar fundamental da História para a filosofia e da linguagem para a fenomenologia e se distanciaram na tarefa de resolver, cada um a sua maneira, seus impasses originários.

${ }^{63}$ Como por exemplo os filósofos Marc Richir, Claude Romano, Alain Badiou e Renaud Barbaras.

${ }^{64}$ Fundamental nos lembrarmos do subtítulo de $O$ ser e o nada: ensaio de ontologia fenomenológica.
}

\begin{tabular}{|c|c|c|c|c|c|}
\hline intuitio & $\begin{array}{c}\text { ISSN } \\
1983-4012\end{array}$ & Porto Alegre & Vol.10- $\mathrm{N}^{\circ} .2$ & $\begin{array}{c}\text { Dezembro } \\
2017\end{array}$ & p. 66-85 \\
\hline
\end{tabular}


ideia de uma fenomenologia da linguagem, três temas são fundamentais: expressividade, verdade e comunicação.

Considerando a expressividade como a condição de manifestar, de alguma maneira, o sentido atribuído pela consciência significante a determinada experiência, Sartre e Ponty entendem a fala (parole) como a instância originária de significação, mas o modo como cada um dos dois pensa o que é a fala é particular. Para tratar da linguagem a partir do tema da expressividade e, especificamente, da fala, é preciso assumir a perspectiva de dentro, por isso, Sartre elege a prosa como o campo privilegiado de pesquisa, ao passo que Merleau-Ponty se volta ao estudo do sujeito falante.

Para Merelau-Ponty, é preciso reconhecer que a fala não é representação ou tradução ${ }^{65}$ do pensamento, e sim que fala e pensamento são a mesma coisa para o sujeito falante ${ }^{66}$, por isso, o pensamento se constrói em conjunto com o discurso porque a sua fala é o seu pensamento verbalizado, vocalizado, mas não traduzido como se a fala fosse uma operação de segunda ordem em relação ao pensamento. E nesse processo de expressividade, a fala termina por expressar mais que se esperava no início, já que o pensamento se dá a conhecer a medida em que o discurso acontece. Merleau-Ponty afirma que há mais na fala que o sujeito acreditava ter colocado nela ${ }^{67}$, pois falar é precisamente dar a conhecer 0 sentido que aos poucos é construído. Sentido e fala são intrinsecamente envolvidos ${ }^{68}$. Importante observar que nesse momento inicial do pensamento pontiano, a fala é pensada como um gesto entre outros, com a particularidade de ser um gesto linguístico ${ }^{69}$, o que significa que a linguagem é estudada de uma maneira secundária, subordinada ao estudo do corpo. O primeiro gesto em relação com sua situação constitui já expressão primordial, pois toda percepção, toda ação, todo uso humano do corpo significa uma operação primária na qual constitui os signos em signos e faz o expresso habitar neles pela expressão da sua configuração e, assim, ao inserir sentido naquilo que era vazio, inaugura uma ordem, uma instituição, uma

\footnotetext{
${ }^{65}$ A mudança na economia interna do pensamento pontiano sobre a expressão e a linguagem será tema de pesquisa futuras, mas não será explorada aqui. Controversa, a teoria pontiana sofre alguma alteração ao longo dos trabalhos e recebe duras críticas, como a de Barbaras, por exemplo, que acusa a Fenomenologia da percepção de, em certo sentido, falhar na compreensão da expressão e da linguagem: "Il n'est pas sûr que la manière dont la perception est explicitée dans cette ouvrage permette de rendre compte de l'expression [...]" (BARBARAS, Renaud. De l'être du phénomène : Sur l'ontologie de Merleau-Ponty. Collection Krisis. Grenoble : Éditions Jérôme Million, 2001, p. 59 e ss).

66 "Il faut reconnaître d'abord que la pensée, chez le sujet parlant, n'est pas une représentation, c'est-à-dire qu'elle ne pose pas expressément des objets ou des relations. L'orateur ne pense pas avant de parler, ni même pendant qu'il parle ; sa parole est sa pensée" (MERLEAU-PONTY, Phénoménologie de la perception. Paris : Gallimard, 1945, p. 209).

67 "Et quant au sujet qui parle, il faut bien que l'acte d'expression lui permette de dépasser lui aussi ce qu'il pensait auparavant et qu'il trouve dans ses propres paroles plus qu'il ne pensait y mettre, sans quoi on ne verrait pas la pensée, même solitaire, chercher l'expression avec tant de persévérance » (MERLEAU-PONTY. Phénoménologie de la perception. Paris : Gallimard, 1945, p. 445).

68 "en réalité elles [a fala e o pensamento] sont enveloppées l'une dans l'autre, le sens est pris dans la parole et la parole est l'existence extérieure du sens" (MERLEAU-PONTY. Phénoménologie de la perception. Paris : Gallimard, 1945, p. 212).

${ }^{69}$ Cf. MERLEAU-PONTY. Phénoménologie de la perception. Paris : Gallimard, 1945, pp. 226, 230.
}

\begin{tabular}{|c|c|c|c|c|c|}
\hline intuitio & $\begin{array}{c}\text { ISSN } \\
1983-4012\end{array}$ & Porto Alegre & Vol.10 - No.2 & $\begin{array}{c}\text { Dezembro } \\
2017\end{array}$ & p. 66-85 \\
\hline
\end{tabular}


tradição $^{70}$. Não se deve, no entanto, pensar a expressão a partir do corpo como uma forma superior da percepção, mas o corpo a partir da expressão e a percepção como uma primeira palavra. $\mathrm{O}$ sujeito se relaciona inicialmente com a sua situação, o corpo expressivo significa o mundo possuído. Depois de 1945, interessado por formular uma teoria da verdade, Merleau-Ponty afirma que a fala não é apenas um gesto, mas o caminho em direção à verdade ${ }^{71}$.

Para Sartre, a fala tem uma função desveladora: falando, desvela-se a situação segundo o próprio projeto de quem fala, cada palavra pronunciada tem a intenção de mudar aquilo que é nomeado, o sentido é percebido previamente pela consciência segundo o projeto daquele que fala e, projetando uma ação que visa alterar a figura do mundo, o sujeito nomeia segundo sua intencionalidade significa ${ }^{72}$. Para Sartre, a fala é um momento particular da ação ${ }^{73}$. A consciência reflexiva posiciona a situação em sua realidade concreta e descobre nela uma falta, um desideratum. O homem cria, logo, um projeto com vistas a sanar essa falta e elabora todo o instrumental para que a modificação aconteça e o resultado projetado seja obtido. A fala é, deste modo, um desses momentos da ação concreta, ou até mesmo vários deles: o momento em que a falta, ou outros elementos constituintes do ato, são enunciados - de modo verbal, disponibilizado aos quatro ventos, ou de apenas de modo individual, como num pensamento, ou ainda de forma escrita ficcional como na prosa ${ }^{74}$.

A linguagem em Sartre e em Merleau-Ponty tem estreita ligação com as artes: com a literatura, em se tratando do primeiro, e com a pintura, para o segundo. Ainda assim, a teoria da linguagem é

70 "Toute perception, toute action qui la suppose, bref tout usage humain du corps est déjà expression primordiale $[\ldots] "$.

71 "[...] la parole n'est pas un geste parmi tous les gestes, mais la parole est le véhicule de notre mouvement vers la vérité, comme le corps est le véhicule de l'être au monde" (MERLEAU-PONTY, Maurice. La prose du monde. Texte établi et présenté par Claude Lefort. Paris : Gallimard, 1969, p. 181).

72 "Ainsi, en parlant, je dévoile la situation par mon projet même de la changer ; je la dévoile à moi-même et aux autres pour la changer ; je l'atteins en plein cœur, je la transperce et je la fixe sous les regards ; à présent j'en dispose, à chaque mot que je dis, je m'engage un peu plus dans le monde, et du même coup, j'en émerge un peu davantage puisque je le dépasse vers l'avenir" (SARTRE, Situations II. Paris : Gallimard, 1948, p. 73).

72 "La parole est un certain moment particulier de l'action et ne se comprend pas en dehors d'elle" ( SARTRE, Situations II. Paris : Gallimard, 1948, p. 75).

73 "La parole est un certain moment particulier de l'action et ne se comprend pas en dehors d'elle" ( SARTRE, Situations II. Paris : Gallimard, 1948, p. 75).

${ }^{74}$ É necessário assinalar que isso não significa que a fala não seja também uma ação, afinal, fala-se para mudar. Ao nomear a conduta de um indivíduo, para ele não é mais possível manter-se indiferente, com a mesma conduta irrefletidamente: ou ele para de agir do modo flagrado e modifica a sua conduta; ou, deliberadamente, procura agir da mesma forma - que, no limite, não poderá mais ser como antes, pois agora cada movimento será meticulosamente planejado para tentar parecer igual aos anteriores. A mudança foi provocada porque houve a fala e a escuta. A fala engajada numa situação atingiu os ouvidos e a liberdade do indivíduo cuja conduta foi nomeada num apelo à sua liberdade para que posicionasse sua ação e, de maneira consciente e refletida, passasse a agir. Do ponto de vista do indivíduo que teve sua conduta narrada, a fala não foi a totalidade da mudança, mas um momento muito particular dela. Do ponto de vista de quem falou, a fala foi por si um ato. O falante engajou-se numa situação captando certa conduta, percebeu nela a falta de algo, em seguida, engendrou meios para suprir a falta, produziu um instrumental linguageiro de verbalização e gestos expressividade que resultou na alteração da figura do mundo.

\begin{tabular}{|c|c|c|c|c|c|}
\hline intuitio & $\begin{array}{c}\text { ISSN } \\
1983-4012\end{array}$ & Porto Alegre & Vol.10 - No.2 & $\begin{array}{c}\text { Dezembro } \\
2017\end{array}$ & p. 66-85 \\
\hline
\end{tabular}


diretamente vinculada a uma concepção de verdade. Podemos nos perguntar, então, como propor uma teoria da verdade a partir da linguagem se ela se liga às artes, isto é, ao reino da imaginação?

Na obra $O$ que é literatura?, Sartre afirma que, em arte, é sempre preciso mentir para ser verdadeiro $^{75}$. A arte cria ilusões e, a partir da força das suas palavras e da sua imagem, faz emergir uma verdade $^{76}$ que talvez a racionalidade filosófica seja realista demais para desvelar. Os diferentes gêneros de escrita não foram limites à expressividade de $\operatorname{Sartre}^{77}$ : ao mesmo tempo que a filosofia é dramática ${ }^{78}$, a ficção exige e remete à filosofia e à visão de mundo do escritor ${ }^{79}$. Nesse sentido, a arte contém não somente a verdade do escritor, mas ela tem a função de desvelar uma realidade ao leitor. Na ficção ${ }^{80}$, o autor desvenda ao público o mundo que ele deseja transformar, uma vez que escrita é sinônimo de ação, o escritor está sempre diante de uma encruzilhada entre o que falar e o que calar ${ }^{81}$.

Na Fenomenologia da percepção, Merleau-Ponty declara que o mistério ${ }^{82}$ que ainda circunda mundo e razão não pode ser um empecilho à filosofia, tampouco visto como um fracasso, pois a verdadeira filosofia é justamente reaprender a ver o mundo e, desse modo, uma história literária pode, legitimamente, significar o mundo com a mesma profundidade que um tratado filosófico ${ }^{83}$. Para o autor: "O mundo fenomenológicco não é a explicitação de um ser prévio, mas a fundação do ser, a filosofia não é o reflexo de uma verdade prévia, mas, como a arte, a realização de uma verdade" ${ }^{84} 85$. A ideia de verdade

${ }^{75}$ Cf. SARTRE, Situations II. Paris : Gallimard, 1948, pp. 327-328.

${ }^{76}$ Em Signes, Merleau-Ponty concorda e retoma a expressão de Sartre: “'Comme toujours en art, mentir pour être vrai', dit Sartre avec raison” (MERLEAU-PONTY. Signes. Paris : Gallimard, 1960, p. 71).

${ }^{77}$ Entrevista a Gabriel d'Aubarède, publicada em 1951, na revista Les Nouvelles Littéraires: "Sartre : - Oh ! les genres, ça n'existe pas !" (AUBARÉDE, Gabriel d'. « Rencontre avec Sartre ». Interview avec Gabriel d'Aubarède. Les Nouvelles Littéraires, Paris. 1. 2. 1951).

${ }_{78}^{78}$ Aujourd'hui, je pense que la philosophie est dramatique" (SARTRE, Situations IX. Paris : Gallimard, 1972, p. 12).

79 "[...] la technique romanesque renvoie toujours à la métaphysique du romancier" (SARTRE, Situations. Paris : Gallimard, 1947, p. 66).

${ }^{80}$ Sobre a relação entre ficção e filosofia em Sartre, conferir minha tese de doutoramento: HILGERT, Luiza Helena. Ontologia e moral na obra ficcional de Sartre (Tese de Doutorado). Universidade Estadual de Campinas - Unicamp, Campinas, (em fase de publicação).

${ }^{81}$ Importante observar que o silêncio, o calar-se, é também um ato engajado e, portanto, uma ação ética, segundo Sartre, além de ser um momento da linguagem: "Ce silence est un moment du langage; se taire ce n'est pas être muet, c'est refuser de parler, donc parler encore" (SARTRE. Situations II. Paris : Gallimard, 1948, p. 75).

${ }^{82}$ A prosa do mundo mantém a ideia de mistério: "Le mystère est que, dans le moment même où le langage est ainsi obsédé de lui-même, il lui est donné, comme par surcroît, de nous ouvrir à une signification" (MERLEAU-PONTY, Maurice. La prose du monde. Texte établi et présenté par Claude Lefort. Paris : Gallimard, 1969, p.162). Conferir especialmente o capítulo L'algorithme et le mystère du langage, pp. 161-181. Carlos Alberto Ribeiro de Moura critica essa ideia de mistério de Merleau-Ponty da forma como ela é pensada desde a Fenomenologia da percepção em razão da linguagem se mostrar como mistério e não como fenômeno a ser apreendido. Cf. MOURA, Carlos Alberto Ribeiro de. Racionalidade e crise: estudos de história da filosofia moderna e contemporânea. São Paulo: Discurso Editorial, 2001, pp. 306-308.

83 . Merleau-Ponty, Phénoménologie de la perception. Paris : Gallimard, 1945, pp. XV-XVII.

84 "Le monde phénoménologique n'est pas l'explicitation d'un être préalable, mais la fondation de l'être, la philosophie n'est pas le reflet d'une vérité préalable, mais comme l'art la réalisation d'une vérité".

${ }^{85}$ MERLEAU-PONTY, Maurice. Phénoménologie de la perception. Paris : Gallimard, 1945, p. XV.

\begin{tabular}{|c|c|l|l|c|c|}
\hline intuitio & $\begin{array}{c}\text { ISSN } \\
1983-4012\end{array}$ & Porto Alegre & Vol.10- $\mathrm{N}^{\circ} .2$ & $\begin{array}{c}\text { Dezembro } \\
2017\end{array}$ & p. 66-85 \\
\hline
\end{tabular}


no mundo fenomenológico é diferente da noção de verdade absoluta, ou de verdade ideal: é verdade como expressão.

No relatório, em ocasião da candidatura ao Collège de France, Merleau-Ponty (1962) conta estar preparando uma obra sobre o problema do pensamento formal e da linguagem, obra na qual pretende formar uma teoria da expressão e da verdade. É a linguagem, explica o filósofo, que retoma e ultrapassa a percepção e nos direciona para o mundo cultural, onde são sistematizados e transmitidos os conhecimentos, os valores, a sabedoria e todos os recursos necessários para nos adaptarmos neste mundo já preenchido de significados e repleto de saberes. A linguagem será também para Sartre essa ferramenta com a qual o homem consegue mais ou menos adaptar-se ${ }^{86}$ no mundo. O mundo é revelado ao homem pela linguagem, que permite a ele descobrir-se como ser-no-mundo e informar-se para poder habitar. $\mathrm{O}$ tema da linguagem em relação com a verdade tem, em Sartre, uma implicação com a ontologia, uma vez que Sartre compreende a linguagem como uma forma privilegiada de desvelamento: nomear é trazer à luz, é elucidar para si e para os outros o que uma coisa é. É a linguagem que carrega a verdade do ser: tanto o ser de quem fala quanto do ser da situação, no sentido de que traz à tona a situação como ela é, em sua verdade, ainda que essa verdade não seja uma verdade absoluta, pura, mas uma verdade situada no horizonte da percepção e da subjetividade humanas.

Na Fenomenologia da percepção e na Estrutura do comportamento, a preocupação do autor foi a de restituir o mundo da percepção; nas obras posteriores a 1945, contudo, o autor deseja ultrapassar o mundo percebido em direção à comunicação com o outro ${ }^{87}$, ao campo do conhecimento propriamente dito, o que exige além de uma teoria da verdade, uma teoria da intersubjetividade ${ }^{88}$. A última etapa, portanto, na direção de pensarmos uma fenomenologia da linguagem se dedica a estabelecer as bases que permitem a comunicação com o outro. Tendo já explorado os temas relevantes a uma teoria da expressividade e a

\footnotetext{
${ }^{86}$ Em $O$ ser e o nada, no capítulo correspondente ao estudo do corpo (Capítulo 2 da Terceira parte), especialmente no momento em que Sartre explica a dimensão fática do corpo, o autor afirma que ao fazer uso de uma ferramenta, um instrumento do mundo, meu corpo se torna um prolongamento desse utensílio e, nesse momento, não usamos o utensílio, mas somos o utensílio, em razão da adaptação que somos pela facticidade do corpo: "Cet instrument, nous ne l'employons pas, nous le sommes. [...] il est mon adaptation même aux outils, l'adaptation que je suis » (SARTRE, L'être et le néant. Essai d'ontologie phénoménologique. Paris : Gallimard, 1943, p. 363, grifo no original). Em $O$ que é literatura? (Situations II. Paris : Gallimard, 1948, p. 71), Sartre defende que as mesmas regras que valem para o corpo, valem para a linguagem: "Nous sommes dans le langage comme dans notre corps [...]". A linguagem é essa adaptação mais ou menos bem-sucedida porque o significado do que é dito não é atribuído apenas por quem fala, o outro terá papel fundamental. Nunca sabemos se significamos o que desejamos. Esse é o tema fundamental da terceira parte da pesquisa, Teoria da comunicação.

87 "Nossos dois primeiros trabalhaos procuravam restituir o mundo da percepção. Aqueles que nós preparamos desejam mostrar como a comunicação com o outro e como o pensamento retomam e ultrapassam a percepção que nos iniciou em direção à verdade". ("Nos deux premiers travaux cherchaient à restituer le monde de la perception. Ceux qui nous préparons voudraient montrer comment la communication avec autrui et la pensée reprennent et dépassent la perception qui nous a initié à la vérité”). MERLEAU-PONTY. «Un inédit de Maurice Merleau-Ponty ». In : Revue de Métaphysique et de Morale, 67e Année, No. 4, Octobre-Décembre 1962, 1962, p. 402).

${ }^{88}$ Cf. MOUTINHO, Luiz Damon Santos. Razão e experiência. Ensaio sobre Merleau-Ponty. Coleção Biblioteca de Filosofia. Rio de Janeiro : UNESP, 2006, p. 260-270.
}

\begin{tabular}{|c|c|l|l|c|c|}
\hline intuitio & $\begin{array}{c}\text { ISSN } \\
1983-4012\end{array}$ & Porto Alegre & Vol.10- $\mathrm{N}^{\circ} .2$ & $\begin{array}{c}\text { Dezembro } \\
2017\end{array}$ & p. 66-85 \\
\hline
\end{tabular}


uma teoria da verdade que, em relação intrínseca com a teoria da expressividade valoriza a fala como passagem ao mundo da cultura e veículo em direção à verdade ${ }^{89}$, cabe, na sequência, fundar as bases para uma teoria da comunicação com o outro.

Para o Sartre de $O$ ser e o nada, o outro sempre me apreende primeiro como objeto e, nesse sentido, a relação com o outro é conflituosa ${ }^{90}$. Nesse momento da filosofia sartriana, a linguagem é uma forma de relação concreta com o outro, fadada ao fracasso porque o sujeito falante não sabe se significa aquilo que intenciona e também porque toda relação com o outro é estabelecida nesse horizonte de má-fé e conflito, condenada, portanto, ao círculo infernal de malogro. Uma emancipação do outro como sujeito no reino da autenticidade ${ }^{91}$ poderia resultar, inclusive, numa nova concepção da comunicabilidade. O diálogo é um terreno partilhado entre mim e o outro, assim como o mundo é o solo da coexistência para MerleauPonty. Moutinho (2006) explica como falar e ouvir são, segundo a teoria pontiana, a mesma operação porque ambos exigem a implicação de um sujeito no outro, do sujeito que fala e do sujeito que ouve, que são conduzidos pela perspectiva de um no outro, ultrapassando a visão sartriana de relação conflituosa e fracassada.

\section{Conclusão}

O exame das estruturas da linguagem pela fenomenologia não é novidade, Husserl, Heidegger, Sartre, Merleau-Ponty, Ricoeur e outros já se aventuraram por esse mesmo caminho. Com o método fenomenológico husserliano, uma gama quase infinita de usos se tornou possível por um leque variado de fenomenólogos, porém é curioso observar como todos fizeram parte, cada um à sua maneira e com um grau diferente, da virada linguística da filosofia contemporânea.

O estatuto da linguagem é discutido por Sartre de maneira ao mesmo tempo central e tangente em todos os momentos da sua trajetória filosófica e literária. O seu envolvimento com a literatura, o teatro e a crítica biográfica pode mesmo ser tomado como evidência da importância da temática da linguagem para este autor, mas a ausência de um livro de teoria da linguagem demonstra o tratamento lateral do tema. $\mathrm{O}$ modo como diferentes escritores - Flaubert, Genet, Mallarmé, Baudelaire - lidaram eles próprios com as diferentes questões acerca da linguagem foi também sujeito de pesquisa, reflexão e tema de escrita para o filósofo. As ideias de Sartre sobre a linguagem estão distribuídas pelos seus textos filosóficos, ficcionais, críticos e biográficos em mais de 50 anos de atividade. A concepção sartriana do estatuto, do papel e do poder da linguagem e da literatura é marcada por dois momentos bastante significativos: o primeiro no

89 “[...] la parole est le véhicule de notre mouvement vers la vérité [...]”. (MERLEAU-PONTY, Maurice. La prose du monde. Texte établi et présenté par Claude Lefort. Paris : Gallimard, 1969, p. 181).

${ }^{90} \mathrm{O}$ que todas as atitudes de relação concreta com o outro de L'être et le néant têm em comum é que “[...] devem ser, portanto, consideradas na perspectiva do conflito, [pois fundamentalmente] o conflito é o sentido original do serpara-o-outro". (SARTRE. L'être et le néant. Essai d'ontologie phénoménologique. Paris : Gallimard, 1943, p. 404).

${ }^{91}$ A conversão moral é proposta por Sartre na obra póstuma Cahiers pour une morale (1983).

\begin{tabular}{|c|c|c|c|c|c|}
\hline intuitio & $\begin{array}{c}\text { ISSN } \\
1983-4012\end{array}$ & Porto Alegre & Vol.10- $\mathrm{N}^{\circ} .2$ & $\begin{array}{c}\text { Dezembro } \\
2017\end{array}$ & p. 66-85 \\
\hline
\end{tabular}


meio dos anos '40 e o segundo na metade dos anos '60. Os primeiros escritos de Sartre estão circunscritos à ideia de engajamento literário, em que o autor exige o papel do escritor engajado em sua época, dedicado a promover mudanças e transformações. O segundo momento acontece mais tarde, em 1960 Sartre atenua a diferenciação polêmica entre prosa e poesia de 1948 e inclui a obra de Mallarmé como do tipo engajado ${ }^{92}$. Anos depois, o filósofo insere em definitivo a poesia no campo da literatura engajada chegando a dotá-la, inclusive, de um caráter desvelador e ético.

Estudar o problema da linguagem em Merleau-Ponty implica, como mencionado, em retomar todo o pensamento husserliano não somente sobre a linguagem, mas desde seus primeiros escritos pois os temas estão todos encadeados. Se, inicialmente, a tendência husserliana era de demarcar o distanciamento entre o mundo natural e o da expressão, depois de 1930 a linguagem está entrelaçada (verflochthen) com nosso mundo. A mudança da concepção husserliana de linguagem marca e influencia profundamente Merleau-Ponty, que trata de acompanhar e compreender a fundo o que significam essas alterações para a fenomenologia da linguagem e para a própria fenomenologia. Depois da virada husserliana com o conceito de Lebenswelt, a historicidade e a encarnação linguística como condição de formação de sentido são concepções fundamentais que serão especialmente importantes para a filosofia merleau-pontiana.

Assim, por uma fenomenologia da linguagem significa tomar a questão do sentido e da significação como abertura existencial segundo a qual o sentido do mundo é desvelado de modo originário pela linguagem. A existência encarnada se desenvolve sobre este fundo da Lebenswelt de relação constante e necessário ao sentido, o que faz da existência humana, existência como significação. A impossibilidade, para o sujeito, de se produzir, de se captar, de se fazer, fora desse universo de sentido, indica que todas as coisas e todas as ações humanas são, no limite, significantes. $\mathrm{O}$ homem nasce no mundo enquanto natureza, mas surge no mundo cultural que o condiciona a partir de um conjunto de estruturas sociais significantes ao mesmo tempo em que lhe exige atribuições de sentido subjetivas e individuais. A historialidade do humano deve ser pensada, então, como o meio formador do desejo de sentido próprio do sujeito, quer dizer, o mundo cultural interiorizado em que a significação se produz como projeto de sentido. Nisso consiste, com efeito, a linguagem em seu sentido primitivo que nos permitirá pensar, em trabalhos futuros, as bases para uma fenomenologia da linguagem ${ }^{93}$ segundo a qual o mundo é comum de sentido e exigência de significação.

92 “É o nosso maior poeta. Um apaixonado, um furioso. [...] Seu engajamento me parece tão total quanto possível: ao mesmo tempo social e poético". ("C'est notre plus grand poète. Un passionné, un furieux. [...] Son engagement me paraît aussi total que possible : social autant que poétique"). (SARTRE. Situations IX. Paris : Gallimard, 1972, p. 14).

${ }^{93}$ Tema das minhas pesquisas atuais.

\begin{tabular}{|c|c|c|c|c|c|}
\hline intuitio & $\begin{array}{c}\text { ISSN } \\
1983-4012\end{array}$ & Porto Alegre & Vol.10- $\mathrm{N}^{\circ} .2$ & $\begin{array}{c}\text { Dezembro } \\
2017\end{array}$ & p. 66-85 \\
\hline
\end{tabular}




\section{Referências}

AUBARÉDE, Gabriel d'. «Rencontre avec Sartre ». Interview avec Gabriel d'Aubarède. Les Nouvelles Littéraires, Paris. 1. 2. 1951.

BARBARAS, Renaud. De l'être du phénomène: Sur l'ontologie de Merleau-Ponty. Collection Krisis. Grenoble : Éditions Jérôme Million, 2001.

DASTUR, Françoise. Heidegger: la question du logos. Paris: Vrin, 2007.

HEIDEGGER, Martin. Brief über den Humanismus. Frankfurt am Main: Vittorio Klostermann, 1947.

. «Die Kategorien und Bedeutungslehre des Duns Scotus“. In: Frühe Schriften. Frankfurt am Main: Vittorio Klostermann, 1972.

Lettre sur l'humanisme. Collection Philosophie de l'esprit bilingue. Trad. Roger Munier. Paris : Aubier Montaigne, 1970.

Etre et temps. Trad. François Vezin. Paris : Gallimard, 1990.

Ser e tempo. Edição em alemão e português (1977). Tradução e organização de Fausto Castilho. Col.

Multilíngues de Filosofia Unicamp. Campinas/SP: Editora da Unicamp; Petrópolis/RJ: Editora Vozes, 2012.

HUSSERL, Edmund. Cartesianische Meditationen und Pariser Vorträge. Den Haag: Martinus Nijhoff, 1950.

Cartesian meditations. An Introduction to phenomenology. Translated by Dorion Cairns. 7 th $\mathrm{Ed}$.

Boston: Martinus Nijhoff Publishers, 1972.

Die Frage nach dem Urprung der Geometrie als intentional-historiches Problem. Mit einem Vorwort von

Eugen Fink. In: Revue Internationale de philosophie. 1 (2), pp. 203-225, 1939. Disponível em:

"https://www.sdvigpress.org/dox/100378/108088.pdf » Acessado em 20/01/2017

Formale und Transcendentale Logik. Halle: Niemeyer, 1929.

. Ideas pertaining to a pure phenomenology and to a phenomenological philosophy. First book. Translated by

F. Kersten. Boston: Martinus Nijhoff Publishers, 1983.

. „Ideen zu einer reinen Phänomenologie un phänomenologischen Philosophie. Allgemeine Eirgührung in die

reine Phänomenologie“. In Jahrbuch für Philosophie und phänomenologische Forschung. Halle: Max Niemeyer Verlage, 1913.

. Idées directrices pour une phénoménologie et une philosophie phénoménologique pures. Tome I. Trad. Paul Ricoeur. Paris : Gallimard, 1950.

. Logique formelle et logique transcendantale. Traduit par Suzanne Bachelard. Paris : Puf, 1977.

Logische Untersuchungen. Leipzig : Verlag Von Veit \& Comp., 1900.

L'origine de la géométrie. Traduction et Introduction par Jacques Derrida. Paris : Presses Universitaires de

France, 1962.

. Méditations cartésiennes. Introduction à la Phénoménologie. Trad. Gabrielle Peiffer e Emmanuel Levinas.

Paris : Vrin, 1953.

. Recherches logiques. Paris: Presses Universitaires de France, 1959

JOSGRILBERG, Rui. "O último Husserl e a linguagem". In: SOUZA, Ricardo Timm de; OLIVEIRA, Nythamar Fernandes de. Fenomenologia hoje II. Significado e linguagem. Coleção Filosofia - 149. Porto Alegre: EDIPUCRS, 2002, pp. 251-268.

MERLEAU-PONTY, Maurice. La prose du monde. Texte établi et présenté par Claude Lefort. Paris : Gallimard, 1969.

Le visible et l'invisible. Suivi de Notes de travail. Texte établit par Claude Lefort. Paris : Gallimard, 1964.

Merleau-Ponty à la Sorbonne. Résumé de cours 1949-1952. Dijon-Quetigny : Cynara, 1988.

Parcours deux : 1951 - 1961. Paris : Verdier, 2000.

Phénoménologie de la perception. Paris : Gallimard, 1945.

Signes. Paris : Gallimard, 1960.

. «Un inédit de Maurice Merleau-Ponty ». In : Revue de Métaphysique et de Morale, 67e Année, No. 4, Octobre-Décembre 1962, pp. 401-409. Disponível em: «http://www.jstor.org/stable/40900691 » Acesso em: 22/11/2016

MOURA, Carlos Alberto Ribeiro de. Racionalidade e crise: estudos de história da filosofia moderna e contemporânea. São Paulo: Discurso Editorial, 2001.

MOUTINHO, Luiz Damon Santos. Razão e experiência. Ensaio sobre Merleau-Ponty. Coleção Biblioteca de Filosofia. Rio de Janeiro : UNESP, 2006.

RICEUR, Paul. À l'école de la phénoménologie. Paris : Vrin, 2004.

SARTRE, Jean-Paul. Cahiers pour une morale. Paris : Gallimard, 1983.

\begin{tabular}{|c|c|l|l|c|c|}
\hline intuitio & $\begin{array}{c}\text { ISSN } \\
1983-4012\end{array}$ & Porto Alegre & Vol.10- $\mathrm{N}^{\circ} .2$ & $\begin{array}{c}\text { Dezembro } \\
2017\end{array}$ & p. 66-85 \\
\hline
\end{tabular}


La responsabilité de l'écrivain. Lagrasse : Verdier, 1998.

. L'être et le néant. Essai d'ontologie phénoménologique. Paris : Gallimard, 1943. Situations. Paris : Gallimard, 1947.

. Situations II. Paris : Gallimard, 1948.

. Situations IV. Paris : Gallimard, 1964.

. Situations IX. Paris : Gallimard, 1972.

Recebido em: 25/10/2017

Aprovado para a publicação em: 30/11/2017

\begin{tabular}{|c|c|l|l|c|c|}
\hline intuitio & $\begin{array}{c}\text { ISSN } \\
1983-4012\end{array}$ & Porto Alegre & Vol.10- $\mathrm{N}^{\circ} .2$ & $\begin{array}{c}\text { Dezembro } \\
2017\end{array}$ & p. 66-85 \\
\hline
\end{tabular}

